\title{
Septoria Leaf Spot of Banana: A Newly Discovered Disease Caused by Mycosphaerella eumusae (Anamorph Septoria eumusae)
}

\author{
Jean Carlier, Marie-Françoise Zapater, Fabienne Lapeyre, David R. Jones, and Xavier Mourichon
}

First, second, third, and fifth authors: Centre de Coopération International en Recherche Agronomique pour le Développement (CIRAD), TA 40/02, avenue Agropolis, 34398 Montpellier, France; fourth author: 12 Charlotte Brontë Drive, Droitwich Spa, Worcestershire WR9 7HU, UK.

Accepted for publication 5 May 2000.

\begin{abstract}
Carlier, J., Zapater, M.-F., Lapeyre, F., Jones, D. R., and Mourichon, X. 2000. Septoria leaf spot of banana: A newly discovered disease caused by Mycosphaerella eumusae (anamorph Septoria eumusae). Phytopathology 90:884-890.

A previously undescribed leaf spot disease of banana has been discovered in southern and Southeast Asia. The fungus identified as the causal agent of this leaf spot has a Mycosphaerella teleomorph stage and a Septoria anamorph stage. Isolation and reinoculation of the fungus to

banana reproduced symptoms and confirmed its pathogenicity. Phylogenic analysis based on sequences of the internal transcribed spacer and 5.8S ribosomal DNA regions from the different leaf spot pathogens of bananas was consistent with the definition of a new species. $M$. eumusae (anamorph $S$. eumusae) is the name proposed for the causal agent and Septoria leaf spot as the name for the disease. The presence of the pathogen has been confirmed in leaf specimens from southern India, Sri Lanka, Thailand, Malaysia, Vietnam, Mauritius, and Nigeria.
\end{abstract}

Two related ascomycete fungi cause the most important leaf spot diseases of banana. Mycosphaerella fijiensis (anamorph Paracercospora fijiensis) is the causal agent of black leaf streak disease (black Sigatoka) and M. musicola (anamorph Pseudocercospora musae) is the causal agent of Sigatoka (15). Another Mycosphaerella species, M. musae, causes a leaf speckle disease that is considered of little importance except in Australia (14). Many other fungal pathogens attack the foliage of banana, but most are of minor importance (14). One of these, Phaeoseptoria musae, is the cause of Phaeoseptoria leaf spot (12). This fungus, which produces symptoms very similar to Sigatoka, was first described in India and has been detected in other countries $(11,12)$. Serious losses due to this minor foliar disease have not been reported (11).

$M$. fijiensis is currently spreading to new banana-growing areas and replacing $M$. musicola, which has an almost worldwide distribution on banana, as the dominant and most serious leaf spot pathogen. Although this spread is well documented in the Australasian, Pacific, African, Latin American, and Caribbean regions (8) it is not as well understood in southern and Southeast Asia because of contradictory reports and conflicting evidence (7).

Between 1992 and 1995, as part of a survey to determine the distribution of black leaf streak and Sigatoka diseases in southern and Southeast Asia, specimens of banana leaf spot were collected from southern India, Sri Lanka, western Malaysia, Thailand, and Vietnam for pathogen identification. Most specimens were an undetermined, pathogenic Mycosphaerella species with Septoria as the anamorph stage. A specimen of this new leaf spot was also collected later in Mauritius in 1997. An analysis of leaf spot fungi in strain collections and diseased leaf samples collected from Nigeria in 1999 revealed that the pathogen has been present in that country since at least 1989. $M$. eumusae (anamorph $S$. eumusae) is the name proposed for the fungus, which is described for the first time in this report.

Corresponding author: J. Carlier; E-mail address: jean.carlier@cirad.fr

Publication no. P-2000-0620-02R

(C) 2000 The American Phytopathological Society
Details of the isolation, culture, characterization, and pathogenicity of M. eumusae isolated from banana leaf specimens collected in southern and Southeast Asia are presented. The phylogenic relationship between $M$. eumusae and other Mycosphaerella species attacking banana was also investigated using nucleotide sequences of internal transcribed spacers (ITS) and 5.8S ribosomal DNA (rDNA) regions. This region has been used to analyze relationships within a variety of fungi (10).

\section{MATERIALS AND METHODS}

Diseased tissue collection. Specimens of Sigatoka-like leaf spots were collected in countries in southern and Southeast Asia between 1992 and 1997 (Table 1). Leaf tissue with advanced symptoms of leaf spot were cut into squares of approximately $20 \times$ $10 \mathrm{~cm}$. These tissues were dried between sheets of newspaper and dispatched by courier for diagnosis within 1 week of collection.

Microscopic observations of diseased tissues. Necrotic lesions found on diseased leaf specimens collected in southern and Southeast Asia were cleared in lactophenol and mounted in lactophenol-cotton blue for microscopic examination. Fruiting bodies associated with these lesions were described, and the fungus was identified.

Fungal isolation, culture, conservation, and in vitro sporuOlation techniques. Diseased banana leaves with necrosis were dried at room temperature for $48 \mathrm{~h}$ and soaked in distilled water for $15 \mathrm{~min}$. Sections of leaves were secured to the underside of the lids of petri dishes containing 3\% water agar. Ascospores were discharged overnight on the agar surface, and single ascospores were transferred to fresh potato dextrose agar medium the next morning. Cultures were incubated at $25^{\circ} \mathrm{C}$. Mycelium fragments from developing colonies were placed in $10 \%$ glycerol, kept for $2 \mathrm{~h}$ at $4^{\circ} \mathrm{C}$, and transferred to liquid nitrogen for long term storage at $-80^{\circ} \mathrm{C}$. Conidial sporulation was induced by culturing on modified V8-juice medium ( $100 \mathrm{ml}$ of V8 juice, $0.2 \mathrm{~g}$ of $\mathrm{CaCo}_{3}$, and $20 \mathrm{~g}$ of agar per liter of medium, $\mathrm{pH}$ 6). Three to five 5-mm-diameter agar plugs were sonicated for $1 \mathrm{~min}$ in $5 \mathrm{ml}$ of water and spread on the medium. Cultures were incubated at $22^{\circ} \mathrm{C}$ for 10 to 14 days 
under $60 \mu \mathrm{mol} \mathrm{m} \mathrm{m}^{-2} \mathrm{~s}^{-1}$ of continuous, cool-white, fluorescent light (9).

Fungal isolates. The isolates studied are listed in Table 1. Fifteen isolates of $M$. eumusae were chosen to represent all of the locations where this new pathogen was detected. The isolates of M. eumusae from Nigeria isolated in 1989 and 1990 were originally identified as $M$. musicola or were unclassified. The other isolates in Table 1 belong to previously identified species of leaf spot pathogens of bananas: M. fijiensis, M. musicola, M. musae, and $P$. musae. All cultures were isolated from infected leaves of bananas and derived from single ascospores.

Inoculations. Isolates were artificially inoculated on cv. Grande Naine (AAA, Cavendish subgroup) approximately 10 weeks after plants were removed from tissue culture. Water was used to dislodge conidia from the cultures and the resulting suspension was adjusted to $10^{4}$ spores per $\mathrm{ml}$. Approximately $1 \mathrm{ml}$ of suspension was sprayed on the lower surface of the youngest leaves of test plants using an artist's airbrush (Sagola 150, Vitoria, Spain). Three plants per isolate were inoculated. Inoculated plants were placed in a saturated atmosphere and incubated at $25^{\circ} \mathrm{C}$. After 1 week, the relative humidity was reduced to $80 \%$. Thereafter, plants were examined for a 10 -week period, two times per week. The type of symptoms were observed, and the appearance of first and final symptoms with necrosis were recorded.

DNA isolation. Isolates were grown on V8 juice medium (300 ml of V8 juice, $3 \mathrm{~g}$ of $\mathrm{CaCo}_{3}$ and $20 \mathrm{~g}$ of agar per liter, $\mathrm{pH}$ 6.0 ) for 2 weeks at $25^{\circ} \mathrm{C}$. Mycelia were harvested and dried for 2 days in an oven at $50^{\circ} \mathrm{C}$. Genomic DNA was extracted using a modification of the method described by Carlier et al. (3). Approximately 50 to $100 \mathrm{mg}$ of dried mycelium was ground with sand, dispersed in $0.8 \mathrm{ml}$ of cetyltrimethylammonium bromide (CTAB) extraction buffer (1\% CTAB, $0.7 \mathrm{M} \mathrm{NaCl}, 50 \mathrm{mM}$ TrisHCL [pH 8.0], $10 \mathrm{mM}$ EDTA [pH 8.0], and $1 \% \beta$-mercaptoethanol) in a $2-\mathrm{ml}$ centrifuge tube, and placed in an oven at $65^{\circ} \mathrm{C}$ for 60 to $90 \mathrm{~min}$ with continuous, gentle rocking. An equal volume of chloroform/isoamyl alcohol (24:1) was added, and the contents were mixed by inversion to form an emulsion. The emulsion was spun for 20 to $30 \mathrm{~min}$ at $2,000 \times g$ and the upper aqueous phase was transferred to a clean 2-ml tube. An equal volume of CTAB precipitation buffer $(1 \%$ CTAB, $50 \mathrm{mM}$ Tris-
HCL pH 8.0, 10 mM EDTA [pH 8.0]) was added, the contents were mixed by inversion, and the mixture was spun at 2,000 $\times g$ for $5 \mathrm{~min}$. The supernatant was discarded, and the pellet was resuspended in $0.6 \mathrm{ml}$ of high-salt TE buffer $(1 \mathrm{M} \mathrm{NaCl}, 10 \mathrm{mM}$ Tris HCL [pH 8.0], 1 mM EDTA [pH 8.0]). DNA was precipitated by adding 2.5 volumes of absolute ethanol at $-20^{\circ} \mathrm{C}$ and centrifuged at $2,000 \times g$ for $5 \mathrm{~min}$. The pellet was resuspended in $0.3 \mathrm{ml}$ of TE buffer containing RNase A at $100 \mu \mathrm{g} \mathrm{ml}^{-1}$, and the tube was incubated for $30 \mathrm{~min}$ at $37^{\circ} \mathrm{C}$. DNA was precipitated again by adding $30 \mathrm{ml}$ of $5 \mathrm{M} \mathrm{NaCl}$ and 2.5 volumes of absolute ethanol at $-20^{\circ} \mathrm{C}$, spun at $2,000 \times g$ for $5 \mathrm{~min}$, washed by adding $2 \mathrm{ml}$ of $70 \%$ ethanol, dried, and resuspended in $100 \mu \mathrm{l}$ of TE buffer. The yield was from 20 to $40 \mu \mathrm{g}$ of DNA per extraction.

ITS amplification and sequencing. The ITS region was amplified and sequenced using primers ITS1 and ITS4 (18). Amplifications were performed in $25-$ or $50-\mu$ l final volumes containing $1 \mathrm{ng}$ of fungal DNA as template, $0.4 \mu \mathrm{M}$ of each primer, $1.5 \mathrm{mM} \mathrm{MgCl} 2,0.2 \mathrm{mM}$ dNTPs, $67 \mathrm{mM}$ Tris-HCL [pH 8.8], $16.6 \mathrm{mM}\left(\mathrm{NH}_{4}\right)_{2} \mathrm{SO}_{4}, 0.1 \%$ Tween 20 and $0.01 \mathrm{U \mu l}^{-1}$ of Taq polymerase (Eurobio, Les Ulis, France). After an initial denaturation step of $7 \mathrm{~min}$ at $94^{\circ} \mathrm{C}, 30$ cycles $\left(=1 \mathrm{~min}\right.$ at $94^{\circ} \mathrm{C}, 1 \mathrm{~min}$ at $60^{\circ} \mathrm{C}, 2 \mathrm{~min}$ at $72^{\circ} \mathrm{C}$ ) were performed, followed by a final extension step for $10 \mathrm{~min}$ at $72^{\circ} \mathrm{C}$. Polymerase chain reactions (PCR) were performed in a PTC100 thermal cycler (MJ Research, Watertown, US). Amplification products were analyzed by electrophoresis in 2\% agarose Tris-borate-EDTA gels. Direct sequencing was carried out by the chain termination technique with a 370A nucleotide sequence analyzer (Applied Biosystems, Foster City, CA). Sequencing was done on both strands from the ITS1 and ITS4 primers, and ambiguities were corrected by comparisons of the electrophoregrams using Sequence Navigator software (Perkin-Elmer, Norwalk, CT).

Sequence analysis. Sequences were aligned using the Clustal $\mathrm{X}$ program (17). A dissimilarity matrix based on the proportion of different nucleotide sites was calculated from the alignment, with transitions and transversions given the same weight (deletions were ignored). A tree was constructed from the distance matrix by the neighbor-joining method, and a bootstrap analysis (1,000 replicates) was carried out using the Clustal X program (17). Phylogenetic analysis was also under-

TABLE 1. Geographic origin, genomic group of banana host, year of collection, and source of isolates studied

\begin{tabular}{|c|c|c|c|c|c|}
\hline Isolate code & Country & Location & Genomic group $^{a}$ & Year & Source $^{b}$ \\
\hline \multicolumn{6}{|c|}{ Mycosphaerella eumusae } \\
\hline 385 & India & Bangalor & Grande Naine, AAA & 1992 & 1 \\
\hline 535 & India & Kannara & Grande Naine, AAA & 1995 & 1 \\
\hline 563 & Sri Lanka & Nugahena & Anamala, AAA & 1994 & 1 \\
\hline 482 & Thailand & Sukothai & Grande Naine, AAA & 1994 & 1 \\
\hline 484 & Thailand & Surat Thani & Williams, AAA & 1994 & 1 \\
\hline 485 & Thailand & Thong Ka Wat & Grande Naine, AAA & 1994 & 1 \\
\hline 670 & Vietnam & Mekong Delta & Pisang Mas, AA & 1995 & 1 \\
\hline 744 & Mauritius & & Grande Naine, AAA & 1997 & 1 \\
\hline 162 & Nigeria & Unknown & $\mathrm{AAB}$ & 1990 & 1 \\
\hline BF735 & Nigeria & Onne & $\mathrm{AAB}$ & 1989 & 2 \\
\hline \multicolumn{6}{|l|}{ M. fijiensis } \\
\hline 009 & Gabon & Ntoum & Unknown & Unknown & 1 \\
\hline $01 \mathrm{~A}$ & Philippines & & & & 1 \\
\hline 122 & Cook Islands & Unknown & AAA & 1989 & 2 \\
\hline \multicolumn{6}{|c|}{ Phaeoseptoria musae } \\
\hline IMI 271341 & Honduras & Unknown & Unknown & 1982 & 3 \\
\hline
\end{tabular}

${ }^{a}$ Cultivar's name or genomic group of banana host.

b $1=$ CIRAD (France); 2 = B. A. Fullerton (Horticulture and Food Research Institute, New Zealand); 3 = International Mycological Institute (England). 
taken with parsimony method and bootstrap resampling using the PHYLIP package (4).

\section{RESULTS}

Field observations. Disease symptoms observed initially were first visible as faint brown streaks. When infection density was low, streaks developed into oval or ellipsoidal lesions with gray centers. However, when infection density was high, developing lesions coalesced, and large areas of leaf tissue became necrotic (Fig. 1A). These symptoms, which closely resembled those of other leaf spot diseases, were observed on cultivars belonging to different genomic groups (Table 1).

Fungal description and identification. Two types of fruiting structures, pycnidia and perithecia, were closely associated in all of the specimens. These structures were more prevalent in lesions
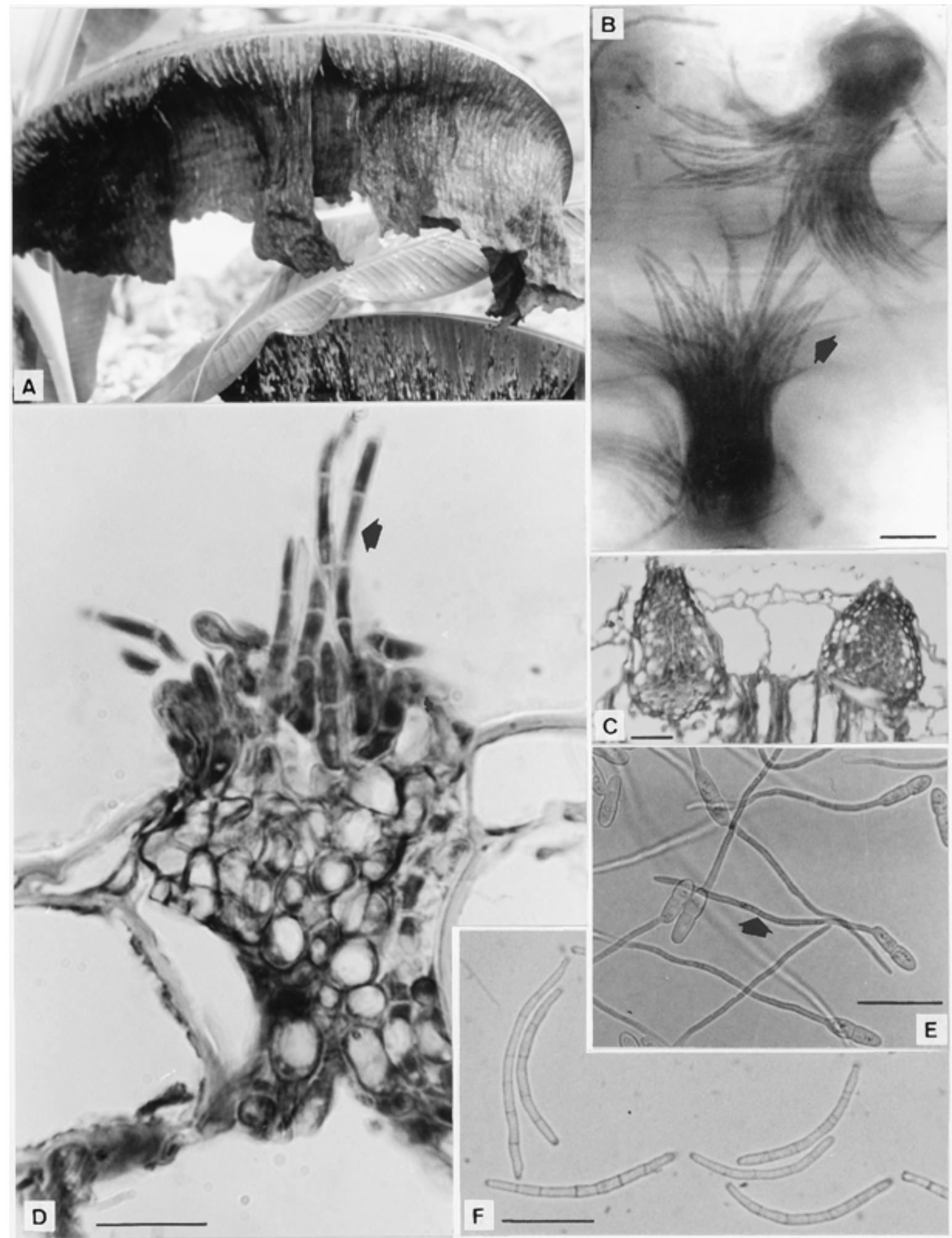

Fig. 1. Photographs of Mycosphaerella eumusae (anamorph Septoria eumusae), cause of Septoria leaf spot of banana. A, Symptoms on naturally infected banana leaves; B, view of pycnidia and conidia (arrow) from naturally infected leaves; C, view of two young, immersed pycnidial bodies; $\mathbf{D}$, section of an acervular-like pycnidium and conidia (arrow) in a necrotic leaf spot; E, germinating ascospores on V8-juice medium. Usually ascospores produce only one germ tube after $24 \mathrm{~h}$ in culture: $\mathbf{F}$, conidia produced from a single-ascospore culture on V8-juice medium. Bars $=20 \mu \mathrm{m}$. 
on upper leaf surfaces. They were characterized from the Mauritius leaf sample. Pycnidia were pear-shaped, 31 to $42 \mu \mathrm{m}$ wide (15 observed), immersed, more or less erumpent, and ostiolated when young (Fig. 1B and C) but often acervular-like when mature (Fig. 1D). Fusiform, hyaline conidia, which were three to five septate and measured between 21.2 and $41.6 \mu \mathrm{m}$ long (20 observed), could be seen in the pycnidia (Fig. 1B and D). This imperfect state of the fungus was identified as Septoria. The conidia were different than those of Phaeoseptoria musae, which are pale brown, obclavate, and smaller in length $(22$ to $30 \mu \mathrm{m}$ [11]). Perithecia were dark brown, 42 to $51 \mu \mathrm{m}$ in diameter (15 observed), amphigenous, scattered, and globose, with a short, protruding ostiole. They had a well-defined dark wall and contained oblong asci. Ascospores were two-celled and measured 12.0 to $16.5 \times 3.0$ to $4.5 \mu \mathrm{m}$ (30 observed; Fig. 1E). These observations allowed us to identify the perfect state of the fungus as Mycosphaerella, which was indistinguishable from the perfect states of M. musicola and M. fijiensis. The fungus was given the name $M$. eumusae (anamorph $S$. eumusae).

Single-ascospore isolation and culture. Cultures of the pathogen, initiated from single Mycosphaerella ascopores ejected from perithecia, had black stroma-like structures and appeared similar to cultures of $M$. fijiensis. After 1 week of incubation in V8-juicemodified medium, pycnidial structures and numerous conidia were produced (Fig. 1F). All the cultures produced hyaline, straight, or slightly flexuous, three- to five-celled conidia. Conidia produced in culture by several isolates were measured (40 conidia observed per isolate; Table 2). Their average size was $40.9 \times 2.1 \mu \mathrm{m}$ (range 24.5 to $53.9 \times 1.8$ to $2.7 \mu \mathrm{m}$ ). The conidia produced on agar media generally were broader and longer than those observed in leaf specimens and were longer than those of Phaeoseptoria musae in culture $(25$ to $33 \times 2.5$ to $3.5 \mu \mathrm{m})$ as described by Punithalingam (11). They were also different from those of $M$. fijiensis and M. musicola.

Pathogenicity. M. eumusae isolates 458, 487, 535, and 670 inoculated on banana cv. Grande Naine (AAA, Cavendish subgroup) were pathogenic. For each isolate, symptoms were observed in all repetitions, and mature lesions were produced in at least one repetition. Initial symptoms were small yellow specks that appeared approximately 20 to 34 days after inoculation. These lesions enlarged and turned pale brown or yellowish gray. Mature lesions, which developed 57 to 82 days after inoculation, were dark brown and usually surrounded by narrow yellow halos. Our objective was to reproduce disease by artificial inoculation. Due to the small number of repetitions for each isolate, statistical analyses were not calculated, and the pathogenicity of isolates were not compared.

ITS sequence analysis. ITS sequence analysis was conducted with two isolates each of $M$. eumusae, M. fijiensis, and $M$. musicola and one isolate each of $M$. musae and P. musae. A single PCR product between 530 and 550 pb was observed for all of the isolates studied using ITS1 and ITS4 primers. Sequencing resolved the exact lengths of the ITS regions, which were similar among species (Table 3). The alignment of the sequences of the ITS region is presented in Figure 2. Comparison with the EMBL database using the BLAST algorithm (1) showed that the ITS sequence from $P$. musae was more related to those from asco-

TABLE 2. Average size and range of conidia ${ }^{a}$ produced in culture by Septoria eumusae isolates

\begin{tabular}{lcc}
\hline Isolate & Average size $(\mu \mathrm{m})$ & Range $(\mu \mathrm{m})$ \\
\hline 487 & 41.6 & $29.0-51.4$ \\
535 & 39.6 & $24.5-53.9$ \\
670 & 43.1 & $29.4-49.1$ \\
744 & 39.5 & $28.9-49.0$ \\
\hline
\end{tabular}

${ }^{\mathrm{a}}$ Estimations based on 40 conidia. mycete fungi belonging to the Leptosphaeria and Phaeosphaeria genera. Phaeoseptoria is one of the anamorphs corresponding to these genera (5). The previously published sequence from $L$. microscopica (Genbank Accession no. U04234) was also included in the analysis. The alignment of the ITS region contained 266 variable sites, 132 of which were phylogenetically informative. From this alignment, a dissimilarity matrix (Table 4) and corresponding tree with bootstrap analysis (Fig. 3) were calculated. Within the Mycosphaerella species, the similarity of the sequences between the two isolates of each of the species used was between $100 \%$ for M. eumusae and $98 \%$ for M. musicola. The similarity of the sequences between two Mycosphaerella species was between $97.8 \%$ for M. eumusae with M. fijiensis and $87.5 \%$ for M. eumusae or M. musicola with M. musae. The P. musae isolate was more related to L. microscopica (similarity of $89 \%$ ) compared with the other Mycosphaerella species (similarity <79\%). Bootstrap analysis indicated that all the branches of the tree were supported at a $95 \%$ confidence level, except the node joining $M$. fijiensis and $M$. eumusae. Similar results were obtained by the parsimony method with bootstrap resampling.

Nigerian isolate 162 (Table 1) that originally could not be identified did not correspond to either M. fijiensis or M. musicola when analyzed. In the study of the global population structure of M. musicola, Nigerian isolates formed a group very distant from other African isolates (H. L. Hayden, E. A. B. Aitken, and J. Carlier; unpublished data). The digested patterns of the ITS regions of the Nigerian isolates using several restriction enzymes were identical to the pattern of one of the M. eumusae isolates. Observation of the morphology of some of these isolates in culture (including isolates 162 and BF735; Table 1) and sequencing of their ITS regions confirmed that they belonged to $M$. eumusae species. These isolates came from two collections and were isolated in 1989 and 1990 (Table 1). A diseased leaf sample from the same Nigerian location (Onne) was analyzed recently. Fifty plants from one field were sampled in 1999. $M$. eumusae and M. fijiensis were isolated from 5 and 28 samples, respectively.

\section{DISCUSSION}

The results presented in this paper show that most specimens of Sigatoka-like leaf spots collected on banana in southern India, Sri Lanka, western Malaysia, Thailand, and Vietnam during the mid1990 s were caused by a previously undescribed pathogenic fungal species. Although a Mycosphaerella stage was present in the leaf specimens, the anamorph stage observed was very different from others previously described on banana, including those of $M$. fijiensis and M. musicola, which are the most important banana leaf spot pathogens (15). The anamorph stage belonged to the genus Septoria. It had pycnidial conidiomata and fusiform, hyaline, and septate conidia with unthickened scars (16). Identical anamorphic fungal structures were produced in pure cultures initiated from single Mycosphaerella ascospores ejected from perithecia in lesions on the leaf specimens, confirming the link

TABLE 3. Size of the internal transcribed spacer (ITS) region of the fungal species studied

\begin{tabular}{llc}
\hline Isolate & \multicolumn{1}{c}{ Species } & ITS region size (bp) \\
\hline 90 & Mycosphaerella musicola & 451 \\
121 & M. musicola & 452 \\
458,487 & M. eumusae & 457 \\
$9,1 \mathrm{~A}$ & M. fijiensis & 446 \\
122 & M. musae & 449 \\
IMI 271341 & Phaeoseptoria musae & 447 \\
Lm & Leptosphaeria microscopica & 504 \\
\hline
\end{tabular}

${ }^{\mathrm{a}}$ GenBank Accession no. U04234. 
M.musicola (90) M.musicola (121)

$M$. eumusae (458)

$M$. eumusae (487)

M.fijiensis (9)

M.fijiensis (1A)

M.musae (122)

P. musae

L. microscopica

M.musicola (90)

M.musicola (121)

M. eumusae (458)

M. eumusae (487)

M.fijiensis (9)

M. fijiensis (1A)

M. musae (122)

P.musae

L.microscopica

M.musicola(90)

M.musicola(121)

$M$. eumusae (458)

$M$. eumusae (487)

M.fijiensis (9)

M.fijiensis (1A)

M. musae (122)

P.musae

L. microscopica

M.musicola (90)

M.musicola(121)

M. eumusae (458)

M. eumusae (487)

M.fijiensis (9)

M.Fijiensis (1A)

M.musae (122)

P.musae

L. microscopica

M.musicola (90)

M. musicola (121)

M. eumusae (458)

$M$. eumusae (487)

M.fijiensis ( 9 )

M.fijiensis (IA)

M.musae (122)

P.musae

L.microscopica

M.musicola(90) M. musicola (121)

M. eumusae (458)

$M$. eumusae (487)

M.fijiensis (9)

M.fijiensis (1A)

M. musae (122)

P. musae

L.microscopica

M.musicola (90)

M.musicola (121)

$M$. eumusae (458)

$M$. eumusae (487)

M.fijiensis (9)

M.fijiensis (1A)

M.musae (122)

P. musae

L. microscopica

10

20

30

40

50

60

70

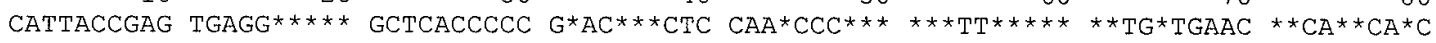

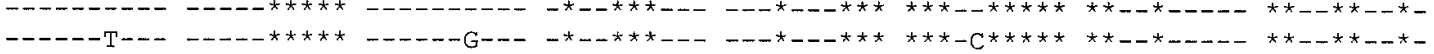

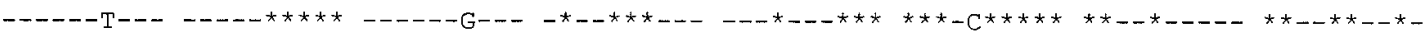

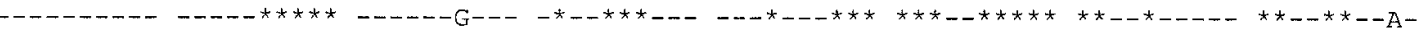

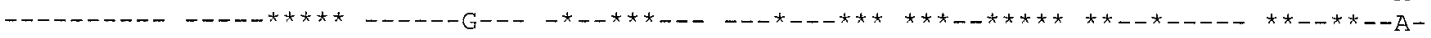

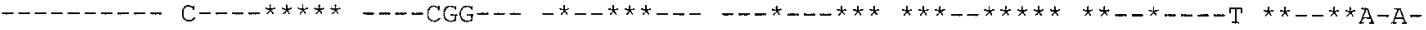

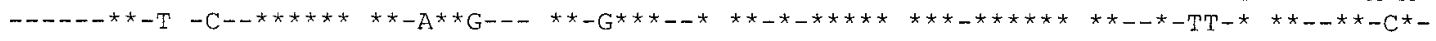
$-\cdots-A^{*}-$ T - C--TAGCTT ---ACTGTCA -G-GGTG--G T--G---GCA TAG--TAATT AC--A-G-G- GG--GG-CCT
100
120
130
140
150
160
170

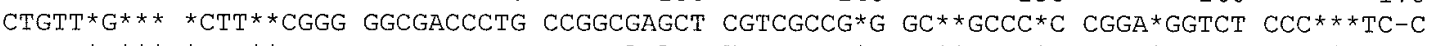
(

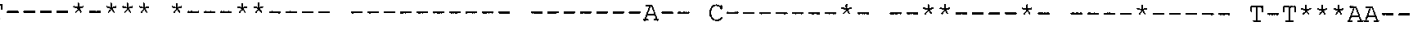

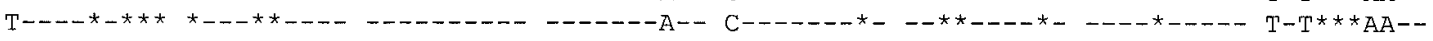

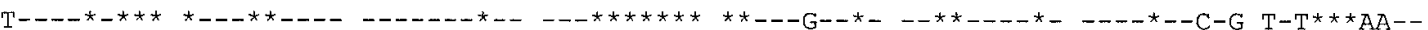

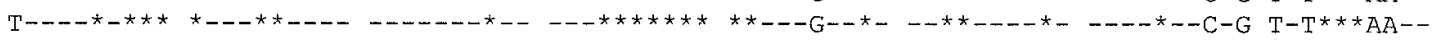

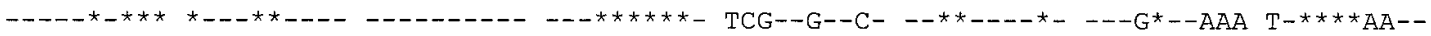

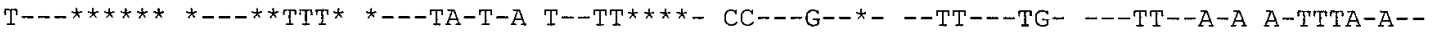
---- T-TAC C---GT-TCC T---CA-*-C AT-TT****- CC---G--*- --TTGCC-G- --ATT--A-A AAACTA-A--
180
190
200
210
220
230
240
250

ACTG***** CATC**TCTG CGTCGGAGTA TGAAACAAAT CGGACAAAAC TTTCAACAAC GGATCTCTTG GTTCTGGCAT

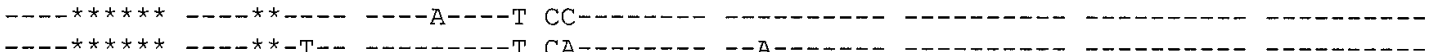

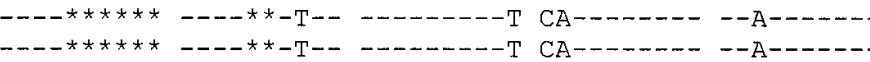

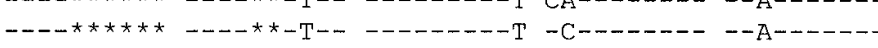

$-\cdots+\cdots * * * *-\cdots+\cdots *-\mathrm{T}---\cdots-----\mathrm{T}-\mathrm{A}$

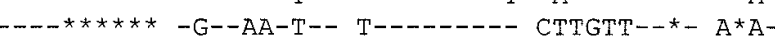

CT-TTTAAAT -T--AA--A- ----T--A-- AT-T----*- A*ATT-C--

*--ATTCAAT TT--AA--A- ----T---*- AA-CTT--*- A*ATT-C---

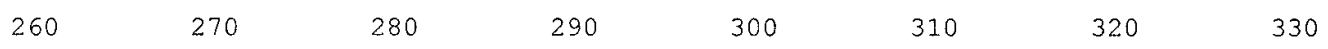

CGATGAAGAA CGCAGCGAAA TGCGATAAGT AATGTGAATT GCAGAATTCA GTGAATCATC GAATCTTTGA ACGCACATTG

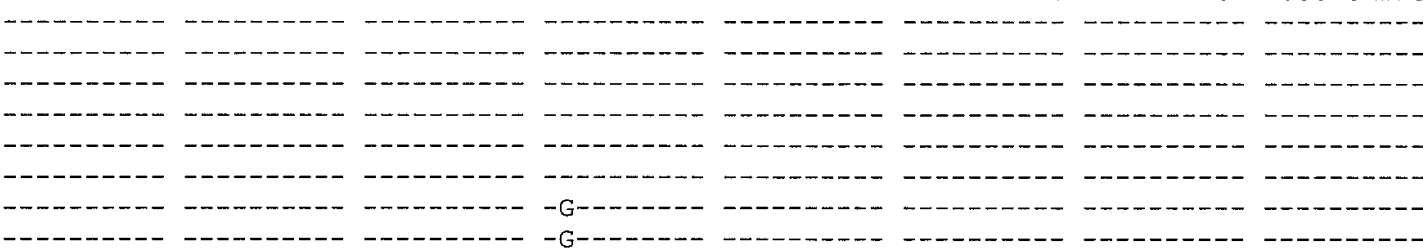

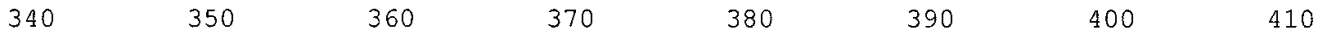
CGCCCTTTGG TATTCCGAAG GGCATGCCTG TTCGAGCGTC ATTTC*ACCA CTCAAGCCTG GCTTGGTATT GGG******* C.-

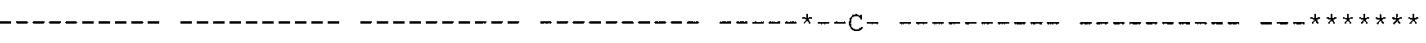
-

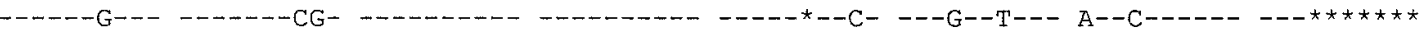

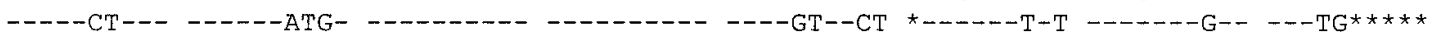
_..-CT $\ldots$ -

$420 \quad 430 \quad 440 \quad 450 \quad 460 \quad 470 \quad 480 \quad 490$ ${ }^{*} \mathrm{C}^{*}$ GCCGCG G---TCCG*C GCGCCCTAAA GT**TCCCGG CTGAGCC*GT CCGTC**TC* T*AAGCGTTG TGG*ATTTTT

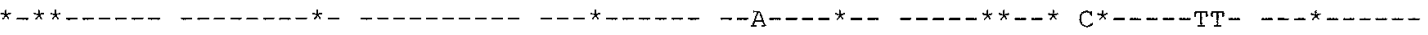

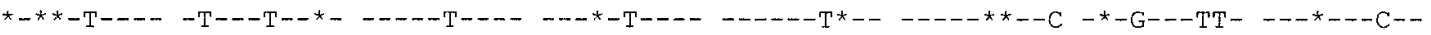

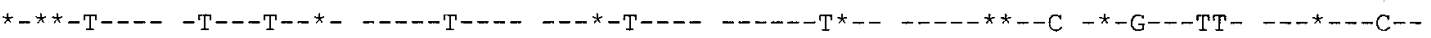

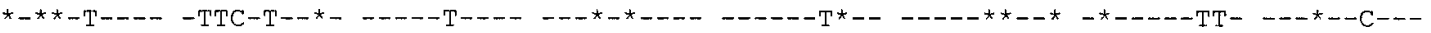

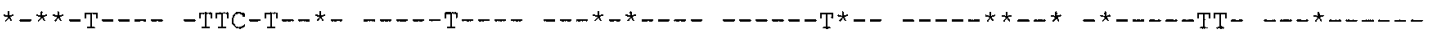

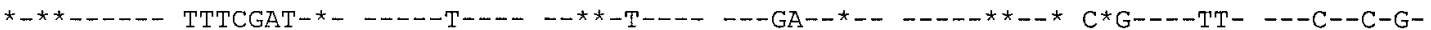
*-TT-T-TTT TT---AA-A- T-A--TC--- ---A-T**-- $-* \star----A--$ GTT-TGG-AG $-\star-----C A-C A C * \ldots-\ldots-$ G

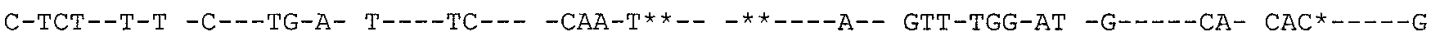

$$
500 \quad 510 \quad 520 \quad 530 \quad 540 \quad 550
$$

CAATTCGCTC CGG*AGT*GC GGGTGGCCGC GGCCGTTAAA TCCT****CA AAGGTTGACC

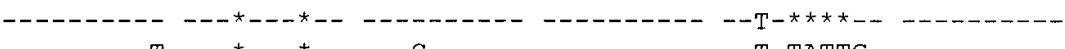

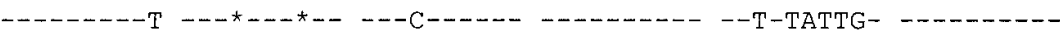

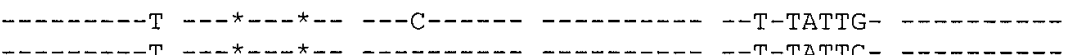

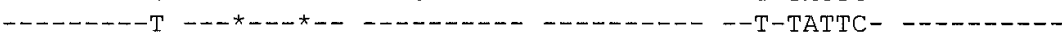

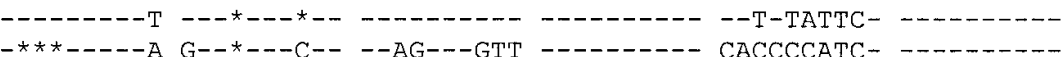

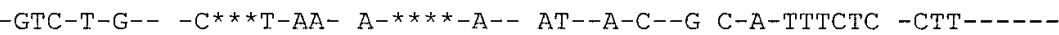

- G---TGG- -TATAA-*A-TT******-_ GT--A-*-G C-TATTTTC- -CTT--.--

Fig. 2. Aligned sequences of the internal transcribed spacer (ITS) region of rDNA of the fungal species studied. ITS1 include base pairs 6 to 216 , the 5.8S coding region extends from base pair 217 to 274, and the ITS 2 extends from base pair 275 to 550. The strain of Phaeoseptoria musae corresponds to IMI Accession no. 271341, and the sequence of Leptosphaeria microscopica corresponds to GenBank Accession no. U04234. - = base homologous with isolate 90. ${ }^{*}=$ possible deletion. M. = Mycosphaerella. 
between the Mycosphaerella and Septoria stages. Symptoms similar to those observed in the field were produced after artificial inoculation with several of these isolates. The fungus identified, thus, was the causal agent of the leaf spots sampled. The name $M$. eumusae (anamorph $S$. eumusae), the cause of Septoria leaf spot disease of banana, is proposed, because this new pathogen was isolated from Eumusae-derived banana cultivars. Type material of banana leaves was deposited in July 1999 at the Laboratoire de Cryptogamie, Museum d'Histoire Naturelle, Paris.

Because Phaeoseptoria leaf spot has been reported in southern India and eastern Malaysia, it was first thought that this and Septoria leaf spot may have been the same disease (2). However, this initial assumption was erroneous, because the causal fungus described in this paper was discovered to be morphologically distinct from Phaeoseptoria musae.

Phylogenic analysis based on sequences of the ITS region of the rDNA from M. eumusae, M. musicola, M. fijiensis, $M$. musae, and Phaeoseptoria musae confirmed that all of these pathogens are different species. The level of homology between isolates within the species studied was high $(>98 \%)$ and similar to that previously published for other species (13). The level of homology between the two M. musicola isolates was lower compared with that of $M$. fijiensis and $M$. eumusae. A greater variability in the ITS1 sequences has been observed within M. musicola compared with $M$. fijiensis, using eight isolates of each species from different origins (6). This result suggests a longer period of divergence within $M$. musicola. Low genetic divergence was found between M. fijiensis, M. musicola, and M. eumusae. These species formed a significant monophyletic group, suggesting that the major leaf spot pathogens of banana may have been derived from a common ancestor. Phylogenic analysis using more Mycosphaerella species isolated from bananas and other plants has been conducted ( $\mathrm{J}$. Carlier and M. F. Zapater, unpublished data). From these ITS sequences, a molecular diagnostic method for the identification of the banana leaf spot pathogens has been developed, using

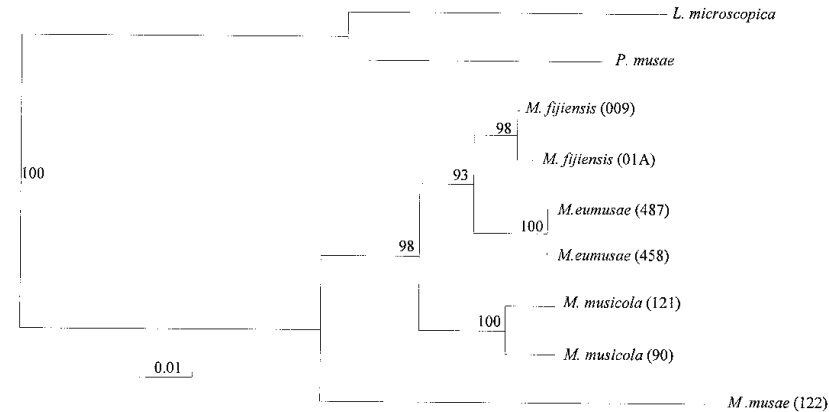

Fig. 3. Dendrogram generated by neighbor-joining analysis of the alignment of the internal transcribed spacer sequences shown in Figure 2. Bootstrap confidence levels, based on 1,000 resamples, are given at the appropriate branches. digestion of PCR-amplified ITS regions with restriction enzymes. Application of this method confirmed that all the M. eumusae strains isolated from the various countries belong to the same species (data not shown).

Fungi causing banana leaf spots have been collected and identified in many countries during the 20th century, but $M$. eumusae had not been described until now. The distribution of $M$. eumusae, thus, may be restricted to the areas where it has recently been found (Table 1). However, further surveys are necessary to determine exactly where this new leaf spot pathogen occurs. The occurrence of the pathogen in Nigeria at an apparently low frequency suggests that it might also be present in other locations where $M$. fijiensis or $M$. musicola are the dominant leaf spot pathogens.

Evidence suggests that the Septoria leaf spot of bananas, first described in this paper, has most likely been mistaken for Sigatoka or black leaf streak in the past based on visual symptoms. Severely diseased plants were observed in the field in southern and Southeast Asia, indicating that the pathogen might cause significant damage. Assessments of the threat that this disease poses to banana cultivation need to be made and quarantine authorities alerted to its existence. Research on all the aspects of the biology of $M$. eumusae is also needed, including studies on host-pathogen interactions and population structure analysis.

\section{ACKNOWLEDGMENTS}

This research was supported by the Centre de Coopération International en Recherche Agronomique pour le Développement (CIRAD) and the International Network for the Improvement of Banana and Plantain (INIBAP). We thank B. A. Fullerton (Horticulture and Food Research Institute, New Zealand), S. P. Beni Madhu (Agricultural Reseach and Extension Unit, Mauritius), and A. Tenkouano (International Institute of Tropical Agriculture, Nigeria) for supplying isolates or leaf specimens.

\section{LITERATURE CITED}

1. Altschul, S. F., Gish, W., Miller, W., Myers, E. W., and Lipman, D. J. 1990. Basic local alignement search tool. J. Mol. Biol 215:403-410.

2. Anonymous. 1995. Musanews. Infomusa 4:26-30.

3. Carlier, J., Lebrun, M. H., Zapater, M. F., Dubois, C., and Mourichon, X. 1996. Genetic structure of the global population of banana black leaf streak fungus, Mycosphaerella fijiensis. Mol. Ecol. 5:499-510.

4. Felsenstein, J. 1993. Phylip (Phylogeny Inference Package). 3.5c. Department of Genetics, University of Washington, Seattle.

5. Hanlin, R. T. 1990. Illustrated genera of ascomycetes. The American Phytopathological Society. St. Paul, Minnesota.

6. Johanson, A. 1993. Molecular methods for the identification and detection of the Mycosphaerella species that cause Sigatoka leaf spots of banana and plantain. Ph.D. thesis. University of Reading, England.

7. Jones, D. R. 1990. Black Sigatoka in the southeast Asian-Pacific region. Musarama 3:2-5.

8. Mourichon, X., and Fullerton, R. A. 1990. Geographical distribution of the two species Mycosphaerella musicola Leach (Cercospora musae) and $M$. fijiensis Morelet (C. fijiensis), respectively, agents of Sigatoka

TABLE 4. Dissimilarity matrix of the internal transcribed spacer region for fungal species studied

\begin{tabular}{|c|c|c|c|c|c|c|c|c|c|}
\hline Isolate & Species & 90 & 121 & 458 & 487 & 9 & $1 \mathrm{~A}$ & 122 & $\mathrm{Pm}^{\mathrm{a}}$ \\
\hline 90 & Mycosphaerella musicola & & & & & & & & \\
\hline 121 & M. musicola & 0.020 & & & & & & & \\
\hline 458 & M. eumusae & 0.049 & 0.046 & & & & & & \\
\hline 487 & M. eumusae & 0.049 & 0.046 & 0.000 & & & & & \\
\hline 9 & M. fijiensis & 0.049 & 0.049 & 0.027 & 0.027 & & & & \\
\hline $1 \mathrm{~A}$ & M. fijiensis & 0.046 & 0.049 & 0.022 & 0.022 & 0.005 & & & \\
\hline 122 & M. musae & 0.122 & 0.125 & 0.125 & 0.125 & 0.110 & 0.112 & & \\
\hline $\mathrm{Pm}^{\mathrm{a}}$ & Phaeoseptoria musae & 0.210 & 0.215 & 0.210 & 0.210 & 0.210 & 0.208 & 0.247 & \\
\hline $\mathrm{Lm}$ & Leptosphaeria microscopicab & 0.220 & 0.222 & 0.225 & 0.225 & 0.225 & 0.220 & 0.254 & 0.110 \\
\hline
\end{tabular}

a Isolate code IMI 271341.

b GenBank Accession no. U04234. 
disease and black leaf streak disease in bananas and plantains. Fruits 45: 213-218.

9. Mourichon, X., Peter, D., and Zapater, M.-F. 1987. Inoculation expérimentale de Mycosphaerella fijiensis MORELET sur de jeunes plantules de bananiers issues de culture in vitro. Fruits 42:195-198.

10. Mugnier, J. 1998. Molecular evolution and phylogenetic implications of ITS sequences in plants and in fungi. Pages 253-277 in: Molecular variability of fungal pathogens. P. D. Bridge, Y. Couteaudier, and J. M. Clarkson, eds. CAB International, Oxon, England.

11. Punithalingam, E. 1983. Phaeoseptoria musae: Description of pathogenic Fungi and Bacteria No.772. Commonw. Mycol. Inst., Kew, England.

12. Raghunath, T. 1963. A new leaf spot of banana from India. Plant Dis. Rep. 47:1084-1085.

13. Sherriff, C., Whelan, M. J., Arnold, G. M., and Bailey, J. A. 1995. rDNA sequence analysis confirms the distinction between Colletotrichum graminicola and C. sublineolum. Mycol. Res. 99:475-478.

14. Stover, R. H. 1972. Banana, plantain and abaca diseases. Commonw. Mycol. Inst. Kew, England.

15. Stover, R. H., and Simmonds, N. W. 1987. Bananas. Longman, New York.

16. Sutton, B. C. 1980. The Coelomycetes: Fungi imperfecti with pycnidia, acervuli and stromata. CAB, Commonw. Mycol. Inst. Kew, England.

17. Thompson, J. D., Gibson, T. J., Plewniak, F., Jeanmougin, F., and Higgins, D. G. 1997. The Clustal X Windows interface: Flexible strategies for multiple sequence alignment aided by quality analysis tools. Nucleic Acids Res. 25:4876-4882.

18. White, T. J., Bruns, T., Lee, S., and Taylor, J. 1990. Amplification and direct sequencing of fungal ribosomal RNA genes for phylogenetics. PCR protocols: A guide to methods and applications. Academic Press, San Diego, CA. 